\title{
6 Indigenous self-determination and data governance in the Canadian policy context
}

\author{
Robyn K. Rowe, Julie R. Bull and \\ Jennifer D. Walker
}

\section{Introduction}

In 2015, Canada's 23rd federally elected Prime Minister, Justin Trudeau, took the nation's stage and vowed to make reconciliation with First Nations, Inuit, and Métis - the three distinct groups of Indigenous Peoples in Canada - a top priority (Galloway, 2015). The Trudeau Liberal government was not the first to address the well-being of Indigenous Peoples as a matter of national concern (Royal Commission on Aboriginal Peoples [RCAP], 1996). Rather, they came into power in Canada at a time when years of research had resulted in a range of recommendations and reports that laid not only the foundation but provided a structure for successful nation-to-nation rebuilding for Indigenous Peoples across the country (RCAP, 1996; TRC [Truth and Reconciliation], 2015). The map toward reconciliation was/is clearly marked and federal-level follow-through continues to be all that is needed. Trudeau's commitment included enacting the Truth and Reconciliation's Call to Action number 43 that calls on the federal, provincial, territorial and municipal governments "to fully adopt and implement the United Nations Declaration on the Rights of Indigenous Peoples [UNDRIP] as the framework for reconciliation" (TRC, 2015, p. 325; Galloway, 2015). More on the TRC will be shared within this chapter. This promise, in turn, reinforced a federal recognition that Indigenous Peoples' have the right to maintain, control, protect and develop Indigenous knowledge(s), information and institutions.

Since his election, Prime Minister Trudeau has repeatedly fortified his promises (Ketonen, 2019; Philpott, 2018); while onlookers across the country - Indigenous and non - wait patiently for a meaningful demonstration of this commitment. Unfortunately, despite the rhetoric in federal politics regarding nation-to-nation relationships and efforts to mobilize reconciliation, little has been done to actually implement the Calls to Action (TRC, 2015) or the UNDRIP (2016). In fact, many Indigenous land defenders and nation supporters are out of patience and are struggling to see Canada's commitment toward reconciliation come to fruition. The rights and jurisdiction of Hereditary Chiefs, who are part of pre-colonial Indigenous governance and leadership structures, are being actively undermined by corporations, with government support, resulting in ongoing threats to land water and traditional Indigenous 
territories (Unist'ot'en Camp, 2020; Indigenous Corporate Training Inc, 2016). Meanwhile, in other ways across the country, individuals, communities and organizations - Indigenous and allied - have been working toward creating the conditions, and building upon many previously formed foundations, in order to mobilize and support Indigenous sovereignty over Indigenous data, policies and programs.

\section{A brief history of policy in Canada}

For many thousands of years, prior to settler arrival, Indigenous Peoples were rich in culture, traditions and languages and lived on the lands that are now called Canada (TRC, 2015). With European arrival and settler expansion, policies were created that stripped First Nations, Inuit and Métis of this diversity while treaties were designed to cede and surrender Indigenous land to the Crown (TRC, 2015). In what has been described as cultural genocide, settler policies were aimed at assimilation and Indigenous elimination (TRC, 2015). These policies were designed to disempower Indigenous governments, undermine inherent Indigenous rights and lead to the surrendering of Indigenous traditional territories (TRC, 2015). This immense cultural disruption lasted for over a century and continues to have an impact on First Nations, Inuit, and Métis in Canada. This impact includes an increasingly widening gap in quality of health care experiences and higher rates of illness and disease (Smylie \& Firestone, 2015; Harris et al., 2011).

The Indian Act (1985) was established in 1876 and is still a large part of the conversation for Indigenous Peoples around health equity and beyond because of its devastating and ongoing effects. The Indian Act "set the stage for a debilitating, systemic public policy that continues, in the modern-day, to powerfully shape patterns of Aboriginal health, social inequity and access to health care and other services" (Richmond \& Cook, 2016, p. 4). In fact, despite the current political discourse toward reconciliation, the federal Indian Act continues to define who is and who is not Indian ${ }^{1}$ under Canadian law (TRC, 2015; Indian Act, 1985).

The government of Canada has accepted its failure to support the health and well-being of First Nations, Inuit, and Métis and has even recognized its shame on the global stage at the UN General Assembly (Philpott, 2018). Canada has openly acknowledged that it has failed to respect Indigenous Peoples' inherent right to self-determination by subjecting First Nations, Inuit and Métis to "laws, policies, and practices based on domination and assimilation" (Philpott, 2018, p. 1650). Enactments of these laws led to child welfare policies, assimilation policies and enfranchisement ${ }^{2}$ policies (Gradual Civilization Act, 1857). In fact, in 1920, the then Deputy Minister of Indian Affairs, Duncan Campbell Scott stated that "our object is to continue until there is not a single Indian in Canada that has not been absorbed into the body politic and there is no Indian question, and no Indian Department" (as cited in the Royal Commission on Aboriginal Peoples, 1996, p. 577). These ideas were (and in some ways still are) so ingrained in social and political thinking that enfranchisement was even referred to as a privilege within the Indian Act (RCAP, 1996). An Act to Encourage the Gradual Civilization of 
the Indian Tribes in Canada of 1857, more commonly known as the Gradual Civilization Act states (1857):

It is desirable to encourage the progress of Civilization among the Indian Tribes in this Province, and the gradual removal of all legal distinctions between them and Her Majesty's other Canadian Subjects, and to facilitate the acquisition of property and of the rights accompanying it, by such Individual Members of the said Tribes as shall be found to desire such encouragement and to have deserved it. (1)

Acting on these policies led to the forced removal of First Nations, Inuit and Métis children from their homes and away from the cultural and linguistic influence of their families and communities (TRC, 2015). In fact, Canada has repeatedly highlighted that the effects of the residential and day school systems (where many First Nations, Inuit and Métis children were taken to be assimilated), its policies and the "historical denial of the rights of Indigenous peoples is directly linked to socioeconomic disparities, including poor health outcomes" (Philpott, 2018, p. 1650). Systemic policies continue to impact Indigenous lives while efforts to reconcile are further challenged by broken promises on the part of governments which reinforce Indigenous mistrust of the health care system (Vogal, 2015).

In order for policies and programs to offer effective solutions to the complex health and social realities that have resulted from ongoing colonization in Canada, quality information is key. Unfortunately, Indigenous health information is often produced and perpetuated by non-Indigenous Peoples for non-Indigenous health policy makers, which results in fragmentation and a continued need for Indigenous activism. For instance, under the provisions of the Constitution Act, 1867 and the Canada Health Act, 1984, health care is a provincial responsibility in Canada. However, under the Indian Health Policy, 1979 and the Indian Act, 1985, health care services for First Nations and Inuit are a federal responsibility (Government of Canada, 2019, 2014; Canada Health Act, 1985; Constitution Act, 1867). The result has been legislative confusion, intergovernmental disputes, and little-to-no accountability on the part of provincial and federal levels of government. A notable and high profile story highlighting the resulting unnecessary bureaucratic delays is the story of Jordan Anderson, a First Nations child whose family lived in a First Nations community who died waiting for care while federal and provincial governments disagreed about who would be responsible for paying for his health services (Government of Canada, 2020; Assembly of First Nations, 2018; MacDonald \& Attaran, 2007). This resulted in the adoption of Jordan's Principle, which emphasizes the importance of prioritizing a child's health care needs at the first point of health care access, and the development of associated policies to put this principle into practice.

Regrettably, reporting on progress with respect to closing health and social gaps between Indigenous populations and other populations in Canada is often reduced to "checking the boxes" on Indigenous health disparities and fails to acknowledge the worldviews and priorities of Indigenous Peoples as autonomous individuals and self-determining collectives (Richmond \& Cook, 2016). Despite 
the overemphasis on negative findings and persistent Indigenous health inequities, First Nations, Inuit and Métis are leading efforts to heal their people and communities through Indigenous-centered use of Indigenous data (Walker et al., 2017). For instance, in some provinces across the country, Indigenous health data is being governed by Indigenous Peoples. In Ontario, administrative health data about First Nations Peoples that is collected and held with the rest of the provinces' administrative health information is governed by First Nations through data governance agreements and internal policies put in place by the data custodian (Walker et al., 2017, 2018). More will be discussed on regionally specific Indigenous health data management throughout this chapter.

\section{Chapter overview}

In this chapter, we recognize the historical and ongoing impacts of colonialism (see, for example, TRC, 2015; National Inquiry into Missing and Murdered Indigenous Women and Girls [MMIWG], 2019; Young, 2015) and we take the position that, while colonialism is ongoing and the intergenerational trauma that has resulted from it are devastating, Indigenous Peoples have been and continue to be resilient Peoples who have worked tirelessly to preserve and advance selfdetermination. Indigenous groups in Canada have laid the foundations for research processes and policies that highlight Indigenous ownership and stewardship of Indigenous data. We highlight this as a critical time to prioritize how Indigenous leadership will translate those Indigenous data governance (ID-GOV) principles into Indigenous Data Sovereignty (ID-SOV) practice and effectively use data for governance. Indigenous groups recognize the importance of good information governance and the potential of information to guide improvements in policy that lead to better health and well-being outcomes for First Nations, Inuit and Métis across the country. In this chapter, we explore the current ID-SOV landscape in Canada and policies that impact ID-GOV and effective policy development. The timing of this work is critical and necessary as Indigenous Peoples in Canada continue to reclaim, regain and restore rights to self-determination, autonomy and self-government.

We begin this chapter in a time of post-contact; in a time already climatized to the Constitution Act of 1867; in a time when the Indian Act of 1876 and federal legislative authority over Indigenous Peoples already exists; in a time following the closure of the last of the residential schools (in 1996); and in a time when the federal government has publicly apologized (in 2008) and taken ownership for creating the discriminatory policies that led to these (and other) systems of oppression and assimilation (Indigenous and Northern Affairs Canada [INAC], 2010). We begin this chapter in a time when Canada has stated its support for the UNDRIP (INAC, 2017); a time when the Truth and Reconciliation Commission of Canada's Calls to Action have been federally acknowledged; and elementary, secondary and post-secondary schools across the country are formally recognizing the legacy of residential schools and students are learning about Canada's colonial history (Laanela, 2016). We begin this chapter in a time when, at 
minimum, the perception of resilience, resurgence and rejuvenation is flourishing. Conversations around Indigenous sovereignty and governance are being heard in broadening public discourse and movements are happening in different ways across the country. We begin this chapter today.

\section{Situating ourselves: research is relational}

The rigid structure of Western institutions, research ethics boards (REBs) and research-funding mechanisms can be contradictory to what is needed for ethical research involving Indigenous Peoples. The systems are historically built on, and maintained by, colonial culture and influences, and often lack meaningful integration of Indigenous epistemologies and sciences. However, Indigenous individuals, researchers and organizations are seeing the benefits of using those systems to access Indigenous data and incorporating Indigenous knowledges into the use of those data (University of Manitoba, 2019; Tui'kn Partnership, 2015). In fact, the integration of Indigenous definitions of health and wellness within data ecosystems can enhance mainstream definitions of illness as more than just 'the absence of disease" by incorporating a whole health model that looks at the emotional, physical, mental and spiritual health of an individual (Castellano, 2015; King et al., 2009; Hart, 2002). Within this chapter, we draw on our combined experiences as Indigenous women and researchers to bring our shared knowledges together to articulate components of the current landscape in Canada regarding ID-SOV and its relationship to policy. Based on our shared and extensive backgrounds in Indigenous Data Sovereignty, health policy, ethics and research governance, we discuss the integration of Indigenous knowledges and the practical application of data sovereignty by First Nations, Inuit and Métis across Canada.

\section{More than two decades of policy promising reconciliation}

Reconciliation processes over the past two decades have pushed governments and the general Canadian public to acknowledge the impact of colonial assimilation policies (TRC, 2015). In this light, First Nations, Inuit and Métis and Canadian policy makers are grappling with how to navigate and improve Canada's complex Indigenous health policy landscape. Systemic policies rooted in the Indian Act are so embedded within health and social structures for Indigenous Peoples and communities that incremental improvements seem futile and widespread overhaul feels urgently needed. First Nations, Inuit and Métis have actively contributed to a number of federal, provincial and territorial efforts that have repeatedly made the promise of renewed and improved relationships between Indigenous Peoples and the Government of Canada (RCAP, 1996; TRC, 2015).

\section{RCAP, TRC and MMIWG}

In the wake of a land dispute that heightened tensions and made national headlines in the summer of 1990 between Mohawk (First Nation) protestors and the town of 
Oka, Quebec in Canada, the Royal Commission on Aboriginal Peoples (RCAP) was established (RCAP, 1996; Goodleaf, 1995). In 1996, RCAP released a fivevolume, 4000-page report with over 400 recommendations and set out a 20 -year plan that aimed to "renew the original relationship and to restore the balance that it represented" between Indigenous people, the Government of Canada, and nonIndigenous people in Canada (RCAP, 1996, p. 39). The report documented and acknowledged Canada's efforts to assimilate and dominate First Nations, Inuit and Métis and laid the foundation for Canada's commitment to renewed relationships over the next 20 years. In fact, the Commission recommended "that the federal government establish a public inquiry to investigate the origin and effects of residential school policies and to recommend remedial action" (The Institute on Governance, 1997, p. 2).

Twelve years later, in 2008, the Truth and Reconciliation Commission of Canada was formed. This positive movement arose not as a result of the RCAP recommendations to the federal government, but rather as a result of a large class action lawsuit and civil litigation led by Indigenous Peoples who attended an Indian residential school (Bak et al., 2017; TRC, 2015).

The TRC came with a mandate to inform all people in Canada of the truth of the lived experiences of the children who survived the residential school system (TRC, 2015). It also aimed to provide an opportunity to guide and inspire healing for survivors, their families and future generations through truth telling; again, in an effort to reconcile relationships between Indigenous persons and the rest of Canada (TRC, 2015). The TRC's work also culminated in a final report that was released in 2015 that placed responsibility for injustices faced by First Nations, Inuit and Métis on the intentionally assimilationist, and discriminatory policies that formed the foundation of the colonial agenda and successive government policies.

According to often-cited and disparaging statistics on Indigenous Peoples in Canada, significant negative health gaps between Indigenous and non-Indigenous groups persist (AFN, 2017; TRC, 2015; King et al., 2009). Indigenous worldviews and traditional medicines continue to be alienated from mainstream health care (MacDonald \& Steenbeek, 2015) and much of the data collected on or about Indigenous groups is done without input from Indigenous Peoples (Canadian Alliance for Healthy Hearts and Minds First Nations Cohort Research Team, 2019). Within the TRC (2015), Calls to Action number 18 and 19 specifically address the current state of Indigenous Peoples' health as a "direct result of previous Canadian government policies, including residential schools" (p. 160). The TRC advises government bodies to "recognize and implement the health-care rights of Aboriginal people as identified in international law and constitutional law, and under the Treaties" (p.160). Further, the Calls recognize the need to "establish measurable goals to identify and close the gaps in health outcomes ... in consultation with" Indigenous Peoples (TRC, 2015, p. 161). The TRC "mainstreamed" conversations about what Indigenous Peoples experienced for the more than 150 years that residential schools were operating across the country and laid out 94 Calls to Action as a new start on a path toward reconciliation in Canada. 
The TRC (2015) called upon all federal, provincial, territorial and Indigenous governments, educational and religious institutions, and all persons in Canada to develop measures to improve the lives of Indigenous Peoples, including health, wellness, education, justice and cultural renewal. While federal-level policy has not officially been changed to reflect the TRC or the government's commitment to reconciliation, the wide-reaching effect of the TRC Calls to Action has resulted in improved policies at various organizational levels. For instance, the Canadian Public Health Association (CPHA) - which is an independent voice for the country on matters of health and that speaks up for individuals to all levels of government-has prioritized reconciliation by embedding the recommendations of the TRC into its policies (CPHA, 2019).

More recently, the Final Report of the National Inquiry into Missing and Murdered Indigenous Women and Girls was released (MMIWG, 2019). Intergenerational trauma, racism, abuse, ongoing economic and social challenges, and violence were prevalent themes discussed within the document. The Final Report also highlights how the current political system is failing to protect Indigenous Peoples. Calls for Justice highlight the ongoing need for cultural renewal and prioritizes appropriate information gathering and reporting on the number of MMIWG. This document affirms that persistent and deliberate human and Indigenous rights violations is the number one reason for the high rates of violence against women, girls and two-spirit, lesbian, gay, bisexual, transgender, queer, questioning, intersex, and asexual (2SLGBTQQIA+) people (MMIWG, 2019).

RCAP, TRC and MMIWG all reflect moments in recent Canadian history when the failure of colonial and subsequent government policies required the establishment of agendas designed to return sovereignty and governance to Indigenous Peoples. These are uplifting examples of Canada acknowledging the inherent rights of Indigenous Peoples; yet, in practice, the true implementation of these priorities and recommendations continues to be met by challenges, false hope and false promises. Each of the reports outline guiding principles grounded in First Nations, Inuit and Métis priorities. Examining each document provides a glimpse through time at social movements and evolving conversations which have led to discussions around data and sovereignty. Each document was a necessity of its time to help address health and wellness gaps for Indigenous Peoples and to offer guiding principles that advance national priorities. Yet today, we see an eerily similar case of tension between Indigenous land defenders, nation supports and the Government of Canada happening that echoes many of the same tensions that happened 30 years ago in Oka except this time protests are happening in support of Indigenous rights, across the country (Unist'ot'en Camp, 2020).

\section{First Nations Principles of OCAP ${ }^{\circledR}$}

In the mid-1990s, structural and administrative challenges associated with the primary collection of Indigenous data were becoming clearer, resulting in an increasing dependence on the use of secondary data within research (Saku, 1999). 
Meanwhile, ongoing amendments to the Indian Act were resulting in changes to who is and who is not considered a "status Indian" in the eyes of the government (Indian Act, 1985). Indigenous data gaps were being exacerbated by questions around identity and it was becoming increasingly challenging to gather accurate census data for individuals "on-reserve" (FNIGC, 2016). In an effort to address this gap, the federal government established the First Nations and Inuit Regional Health Survey (RHS) in order to specifically collect data from on-reserve populations (FNIGC, 2016). As a result, space was made within Canadian research environments that had the potential to reflect the socioeconomic aspirations, governance and jurisdiction of First Nations and Inuit in the country.

Recognizing data as a renewable and valuable resource with the potential to inflict policy change, the First Nations data governance movement began through the assertion of OCAP ${ }^{\circledR}$ principles, which outline the rights of First Nations to own, control, access and possess First Nations data (FNIGC, 2016, 2018). The First Nations Principles of OCAP ${ }$ sparked a catalyst in the advancement of data sovereignty and governance for Indigenous groups across the country and beyond. These principles established clear expectations that have been essential to redirecting funding and efforts to ensure that First Nations have resources for data collection and storage at national and regional levels (FNIGC, 2016, 2018).

\section{Learning and growing from $O C A P \circledR$}

Guided by OCAP ${ }^{\circledR}$ principles, in the year 2000, the Organization for the Advancement of Aboriginal Peoples Health which was later renamed the National Aboriginal Health Organization (NAHO) was established as an Indigenous-led and Indigenous-controlled not-for-profit organization with the mission of improving the physical, mental, emotional, social and spiritual health of Indigenous Peoples, families and communities (NAHO, 2017). NAHO recognized the complexities of Indigenous groups and established three centers: the First Nations Center, the Inuit Tuttarvingat and the Métis Center. In keeping with the priorities of Indigenous self-determination, NAHO worked to advance the individual and community needs of First Nations, Inuit and Métis through these three established centers.

Over time, the Inuit Qaujisarvingat (kow-yee-sar-ving-at) knowledge and research ethics priorities were transferred to the Inuit Tapiriit Kanatami (ITK), which prioritizes the advancement of Inuit self-determination at a national level in Canada (NAHO, 2017). ITK developed the National Inuit Strategy on Research (NISR) which lays the path toward improved policies, programs and services that address social, cultural, political and environmental priorities facing the Inuit. Specifically, the NISR makes recommendations to be addressed by political leaders that are working toward advancing reconciliation. These recommendations aim to advance Inuit governance in research, enhance the ethical conduct of research, align funding with Inuit research priorities, ensure Inuit access, ownership, and control over data and information and build capacity in Inuit Nunangat research (ITK, 2020, 2019). 
Within NAHO, the Métis Center was a Métis-controlled national center that was dedicated to the improved health and wellness of all Métis in Canada (NAHO, 2017). Principles on ethical Métis research have been available for at least a decade that speak to reciprocity, relationships, respect, diversity, safety, inclusivity and appropriate outcomes (NAHO, 2017). In June of 2019, in what Prime Minister Justin Trudeau highlights as a "model of what reconciliation can be" (The Canadian Press, 2019a), self-governance agreements were signed between the federal government in Ottawa and the Métis nations of Alberta, Ontario and Saskatchewan (The Canadian Press, 2019b). Ideally, this historic step could mean that the Métis nations of these three provinces can improve policy and data environments, increase access to programs and services and ultimately improve Métis health and wellness.

NAHO was an internationally recognized producer of collaborative, community-led initiatives that included research and information on Indigenous individuals, families and communities. Core funding for NAHO's programming was provided by Health Canada until funding was cut in the 2012 federal budget which also led to the elimination of NAHO's centers (NAHO, 2017). While many of the programs from the NAHO centers were transferred to other established organizations, the elimination of NAHO and its centers is, unfortunately, another striking example of the federal government's failure to sustain meaningful commitments to reconciliation. It highlights the government's failures to honor Indigenous health priorities, to stand by their own apology for past government policies (INAC, 2010) and to follow through on their own commitments to improved relationship, reconciliation and improved health for Indigenous people (RCAP, 1996).

\section{Impediments to the full implementation of $O C A P{ }^{\circledR}$}

Despite Canada's internationally recognized strengths in quality health care and public policy, challenges persist. Legislative obstacles continue to burden the operationalization of true data governance for First Nations, Inuit and Métis. This is demonstrated within the federal government's current relationship and imposed responsibility toward First Nations (Indian Act, 1985). Because of this relationship, "Canada collects and holds a significant amount of information on First Nations people" (FNIGC, 2014, p. 2). This information is regulated by the Access to Information Act (Government of Canada, 1985a), the Privacy Act (Government of Canada, 1985b) and the Library and Archives of Canada Act (2004). Gaps in these policies as they relate to First Nations governance and the full implementation of OCAP ${ }^{\circledR}$ principles lead to unfavorable conditions which limit First Nations' authority over information that is relevant to First Nations individuals and communities (see FNIGC, 2014). While these gaps have been pointed out specifically by the First Nations Information Governance Center as being impediments for the implementation of OCAP ${ }$, holes within privacy and information legislation that limit governance and autonomy impact all Indigenous lives and communities. 
Regardless, Indigenous Peoples and organizations are partnering with scholars across the country to advance community engagement processes that lead to improved Indigenous data governance. The ripple effects of Indigenous Peoples asserting our inherent rights over our data has expanded beyond the First Nations' Principles of OCAP ${ }^{\circledR}$ within a space that has largely been dominated by settler worldviews. It has expanded to incorporate Indigenous-led and Indigenous-based research protocols, Indigenous jurisdictional control and a growing momentum toward best practices for how to conduct research using First Nations, Inuit and Métis data (Canadian Institutes of Health Research, Natural Sciences and Engineering Research Council of Canada, \& Social Sciences and Humanities Research Council, 2018; FNIGC, 2016; TRC, 2015; RCAP, 1996). The First Nations Principles of OCAP ${ }^{\circledR}$ began by setting the standard for First Nations research and continues to guide how First Nations' data should be collected, used, stored and shared (FNIGC, 2016). Today, OCAP ${ }^{\circledR}$ continues to advance and has led to growing relationships between Indigenous groups and Indigenous researchers and allies who recognize the need for respectful and relevant research approaches that go beyond mainstream research approaches (see, for example, University of Manitoba, 2019; Pyper et al., 2018; Walker et al., 2018; Tui'kn Partnership, 2015).

\section{Assessing Indigenous data quality in Canada}

Following decades of work on Indigenous governance and gaining momentum in the wake of the Government of Canada's stated commitment to reconciliation and relationship building, First Nations, Inuit and Métis governance organizations are working toward strengthening Indigenous data governance, capacity and research innovation (see Walker et al., 2018; Smylie et al., 2018). Indigenous communities and organizations are reclaiming and asserting control over Indigenous data through the enactment of information governance at regional-specific levels. However, deficiencies in data quality, data relevance and data infrastructure continue to exist within First Nation, Inuit and Métis statistics (Smylie \& Firestone, 2015).

Indigenous health information is often lacking consistent, inclusive and reliable information on Indigenous identity (Smylie \& Firestone, 2015). This is largely because of the diversity of Indigenous groups within Canada and a lack of Indigenous identifiers within national health information.

While proxy Indigenous identification based on geographic location has been used in some research, this method is not as effective as having built-in Indigenous identifiers and geographic location is more effective for some Indigenous groups than others (Smylie \& Firestone, 2015) While First Nations, Inuit and Métis make up the three distinct groups of Indigenous people in Canada, there are many subpopulations within these groups. Some groups are more likely to reside in different regions of the country, for example Inuit in northern regions and First Nations people on reserves designated by the Indian Act. In addition, different groups fall under varying degrees of federal, provincial and territorial jurisdiction (Smylie \& Firestone, 2015). Federal, constitutional and treaty obligations add additional layers 
of complexity and potential fragmentation. An inability to link across multiple datasets that contain vital information about Indigenous identity, health services and determinants of health presents further challenges to the quality of Indigenous health data ecosystems (Smylie et al., 2018). These data deficits have led to prolonged challenges for Indigenous and non-Indigenous organizations, systems and services who are working to prioritize the health care needs of First Nations, Inuit and Métis. These points speak to Canada's long history of assimilatory practices and the "historic indifference to cultural specificity" (FNIGC, 2019, p. 56).

\section{Governance in action}

Currently, there is no cohesive or collective ID-SOV movement that includes all Indigenous groups in Canada. However, First Nations, Inuit and Métis peoples, communities and organizations across the country are working toward aligning ethical tensions and data sovereignty priorities with community, individual and collective worldviews. In an age of complex and rapidly changing digital ecosystems and big data, Indigenous Peoples are increasingly aware of the power of data as a resource that has far-reaching ethical, legal, medical and policy implications. More and more Indigenous groups are guiding data-driven advocacy and policy development. Indigenous and non-Indigenous Peoples are collectively recognizing and most-importantly, operationalizing Indigenous worldviews in order to promote the appropriate use and protection of First Nations, Inuit and Métis data.

In prioritizing data collection opportunities, Indigenous groups across Canada have advanced data stewardship and health data initiatives through technological advancements, unique partnerships and formalized data sharing agreements. First Nations, Inuit and Métis are each working at creating guidelines that offer best practices for how to conduct research using their nation-specific data. This is demonstrated by numerous efforts happening across the country. For instance, guided by the OCAP ${ }^{\circledR}$ principles, the Mustimuhw Community Electronic Medical Record (CEMR) (pronounced Moose-tee-muk) is a First Nations-owned health information system that is First Nations-designed and community based (Mustimuhw Information Solutions, n.d.). Currently, the Mustimuhw CEMR is being used by First Nations, health services and health authorities across the country in Alberta, British Columbia, Saskatchewan, Manitoba and Ontario (Mustimuhw Information Solutions, n.d.).

In Nova Scotia, the Tui'kn Partnership is a health collaborative that includes five First Nations communities on Cape Breton Island and is aimed at promoting joint planning that respects the mutual interests of the individuals, families and communities involved (Tui'kn Partnership, 2015). Further, understanding the value of data linkage in relation to improved health policy and positive health outcomes, the Unama'ki Client Registry through the Tui'kn Partnership has led to governance through data sharing agreements between the five involved First Nations, the Nova Scotia Department of Health and Wellness, and Health Canada. The Unama'ki Client Registry is the first community-owned, locally designed registry of its kind in Canada (Tui'kn Partnership, 2015). In Newfoundland and Labrador, Indigenous 
Administrative Data Identifier Standard is setting and prioritizing administrative Indigenous health data quality standards for First Nations, Inuit and Métis in Newfoundland and Labrador (Department of Health and Community Services Newfoundland and Labrador Center for Health Information, 2017).

In Ontario, relationship building between ICES (a research institute that houses health-related data for Ontario), the Chiefs of Ontario (an advocacy and action body for the 133 federally recognized First Nations communities in Ontario), and other First Nations communities and organizations in Ontario has led to unique governance agreements and the linking of the Indian Register (includes status First Nations persons who are registered under the Indian Act) to the databases that house routinely collected provincial health administrative data (Pyper et al., 2018; Walker et al., 2017, 2018). This has led to research that has the capacity to uncover the status of health priorities that are unique to status First Nations Peoples living on and off reserve in Ontario, including diabetes (Slater et al., 2019; Walker et al., 2020, 2018), cancer (Chiefs of Ontario et al., 2017), opioid use (Eibl et al., 2017), aging (Walker et al., 2019) and mortality (Mamow Ahyamowen Partnership, 2019).

The First Nations Health and Social Secretariat of Manitoba (FNHSSM, 2019) prioritized health governance over health systems planning, policy development and health research. In 2019, a partnership between the Manitoba Center for Health Policy and FNHSSM resulted in the successful release of a report on the health of First Nations Peoples in Manitoba (University of Manitoba, 2019). This report is the result of formal research partnerships, information sharing agreements and First Nations health data linkage, "these agreements are historic in the formal recognition of First Nation data governance, in which First Nations exercise their inherent right to self-determination through oversight of their own data" (Katz et al., 2019, p. 3). In British Columbia, First Nations' Data Governance Initiative has established priorities around data and information governance that adhere to the need for timely access to accurate information (BCFNDGI, n.d.). The Alberta First Nations Information Governance Center (AFNIGC) upholds the principles of OCAP $\AA$ and provides regular information, training, data collection, analysis and dissemination of that information through regularly released factsheets for and by Alberta First Nations (AFNIGC, 2015).

In the absence of a collective ID-SOV movement, these important local and regional movements continue to advance data governance and prioritize data sovereignty for First Nations, Inuit and Métis. Leaning on the best practices, policies, guidelines and priorities of other nations across the country can help to ensure that data can be used by, for and with Indigenous populations in ways that foster self-determination and well-being for First Nations, Inuit and Métis individuals, families and communities.

\section{Indigenous Data Sovereignty in Canada today: a work in progress}

Efforts Across the country highlight policy shifts that enable increased Indigenous control over Indigenous research and data through regional and local partnerships. 
Indigenous and non-Indigenous individuals, communities and organizations are actively pursuing change and rising to the challenge of applying current ID-SOV and ID-GOV principles and priorities throughout their work. Many of these regional efforts rely on the strong foundation set by RCAP, the TRC and UNDRIP as guides and supports for the path forward. It is safe to say that Indigenous Data Sovereignty is a work in progress in Canada.

Many Indigenous scholars are feeling the landscape shift as precedent-setting priorities such as the Articles in the UNDRIP, the Calls to Action in the TRC, and the Calls for Justice in the MMIWG report are being recognized by federal, provincial, territorial and municipal-level governments. Yet, bold statements and government commitments to reconcile have not translated into the kind of national-level policy change and development that is needed to truly advance reconciliation. Data in the form of regularly collected administrative health care information have the capacity to create change by identifying health patterns, risks and trends and targeting specific programs that can help move populations to healing. Yet, despite this ongoing recognition, in the year 2020, many First Nations, Inuit and Métis communities lack access to "the minimum standards for the survival, dignity, and well-being" (UNDRIP, 2016) through appropriate health care, safe drinking water and equitable education.

Ultimately, a stronger commitment on the part of the federal government is needed to improve Indigenous health and the full implementation of ID-SOV principles in Canada. It is widely recognized that Indigenous priorities in urban, rural and remote First Nations, Inuit and Métis communities continue to be unaddressed (College of Family Physicians in Canada, the Indigenous Physicians Association of Canada, and the Society of Rural Physicians of Canada, 2019), even as we enter the year 2020, nearly two and a half decades after the recommendations of the RCAP. Yet, it is hard to forget that 30 years ago, conversations around information ownership, control and access of data for First Nations, Inuit and Métis were only just whispers. Today, these principles are widely recognized and increasingly understood. It is our hope that we will look back in 30 years at the road we have not yet traveled and see that Indigenous leaders are harnessing the power of data to inform their governance to impact nation-to-nation government policy. On the journey toward Indigenous Data Sovereignty and governance in Canada, it is empowering to see the ripple effects that small acts of sovereignty and governance are having across our nations and populations.

What is clear is that Indigenous-led initiatives are lighting the way forward for Indigenous Data Sovereignty and governance in Canada. Indigenous-led experience in developing Community EMRs such as Mustimuhw, and data linkage agreements such as the partnership between ICES and the Chiefs of Ontario, or the Unama'ki Client Registry generates new Indigenous knowledge that can be shared to help other Indigenous nations across Canada in their journeys to data sovereignty. Through measures that ensure autonomy and self-determination, the analysis of large datasets can lead to quality health care, can promote safe communities, and increase the cultural, educational and recreational resources available to First Nations, Inuit and Métis. Perhaps it is time to recognize that a new approach to 
policy development in Canada is needed. With the amount of research and information available today through the many initiatives that have been ongoing for over 20 years, it is no longer a conversation about complexity. Priorities and policy suggestions outlined within the RCAP, the UNDRIP, the TRC and the National Inquiry into MMIWG have acted as vessels of active resistance. Indigenous nations know that the path forward is complex and have already contributed to the plan for how to address this. It is time to force the production of policy where Indigenous Peoples are equal collaborators with the government throughout the policy production process. It is time for First Nations, Inuit and Métis communities to define what nationto-nation rebuilding looks like. But most importantly, today, it is time for action.

\section{Notes}

1 Indian is a legal term that was imposed on First Nations, Inuit and Métis by the Government of Canada and continues to be used within legal documents today such as the Indian Act.

2 As part of an assimilatory practice, the Gradual Civilization Act of 1857 was designed as a way for status Indians (under the Indian Act) to enfranchise themselves by surrendering their legal and ancestral identities (Crey, 2009).

\section{References}

Alberta First Nations Information Governance Centre. (2015). Welcome to the Alberta First Nations Information Governance Centre. http://www.afnigc.ca/main/index.php?i $\mathrm{d}=$ home.

Assembly of First Nations. (February, 2017). The First Nations Health Transformation Agenda. https://www.afn.ca/uploads/files/fnhta_final.pdf.

Assembly of First Nations. (2018). Accessing Jordan's Principle: A Resource for First Nations Parents, Caregivers, Families and Communities. https://www.afn.ca/uploads/ Social_Development/Jordan\%27s\%20Principle\%20Handbook\%202019_en.pdf.

Bak, G., Bradford, T., Loyer, J., \& Walker, E. (2017). Four views on archival decolonization inspired by the TRC's calls to action. Fonds d'Archives, (1). doi:10.29173/fa3.

British Columbia First Nations' Data Governance Initiative. A Comprehensive Approach to Governing, Measuring and Reporting on Investments in First Nations Well-Being. https://www.bcfndgi.com/.

Canada Health Act, c. C-6. (R.S.C., 1985). https://laws-lois.justice.gc.ca/eng/acts/c-6/p age-1.html.

Canada Health Act. 1984, c.6, s.1 Crombie, D. (1979). Statement on Indian Health Policy. Government of Canada, Ottawa. http://publications.gc.ca/site/eng/9.865662/ publication.html.

Canadian Alliance for Healthy Hearts and Minds First Nations Cohort Research Team. (2019). "All About Us": Indigenous Data Analysis Workshop — capacity building in the Canadian Alliance for Healthy Hearts and Minds First Nations Cohort. CJC Open, 1(6), 282-288. doi:10.1016/j.cjco.2019.09.002.

Canadian Institutes of Health Research, Natural Sciences and Engineering Research Council of Canada, and Social Sciences and Humanities Research Council. (December 2018). Tri-Council Policy Statement: Ethical Conduct for Research Involving Humans. https://ethics.gc.ca/eng/policy-politique_tcps2-eptc2_2018.html. 
Canadian Public Health Association. (October 2019). Policy Statement: Indigenous Relations and Reconciliation. https://www.cpha.ca/sites/default/files/uploads/about/r econciliation/Indigenous-reconciliation-policy-e.pdf.

Castellano, M.B. (2015). The spiritual dimension of holistic health: a reflection. In M. Greenwood, C. Reading, N.M. Lindsay, \& S. Leeuw (Eds.), Determinants of Indigenous Peoples' Health in Canada: Beyond the Social (pp. 33-37). Canadian Scholars' Press.

Chiefs of Ontario, Cancer Care Ontario and Institute for Clinical Evaluative Sciences. (2017). Cancer in First Nations People in Ontario: Incidence, Mortality, Survival and Prevalence. Toronto: Chiefs of Ontario, Cancer Care Ontario and Institute for Clinical Evaluative Sciences.

Constitution Act, 30 \& 31 Vict, c 3. (1867). https://www.canlii.org/en/ca/laws/stat/30---31 -vict-c-3/97547/30---31-vict-c-3.html.

Crey, K. (2009). Enfranchisement. Indigenous Foundations. https://Indigenousfoundat ions.arts.ubc.ca/enfranchisement/.

Department of Health and Community Services Newfoundland and Labrador Centre for Health Information. (December, 2017). Newfoundland and Labrador Indigenous Administrative Data Identifier Standard. National Inquiry into Missing and Murdered Indigenous Women and Girls. https://www.mmiwg-ffada.ca/wp-content/uploads/2019 /05/40-NL_Indigenous_Administrative_Data_Identifier_Standard_FINAL_2017-12 -12.pdf.

Eibl, J., Fung, K., Giannakeas, V., Gomes, T., Henry, D., Martins, D., Pyper, E., Walker, J., Antone, T., Carr, L., deGonzague, B., Jones, C., King, E., Yurkiewich, A., Binguis, N., Corbiere, Y., Davis Hill, L., Desmoulin, J., Hill, P., Logan, M., Mandamin, N., Nicholas, S., \& Williams, S. (2017). Opioid Use among First Nations in Ontario. http:/ /www.chiefs-of-ontario.org/wp-content/uploads/2019/05/Opioid-Use-Among-First-Na tions-in-Ontario-2017-10-05.pdf.

First Nations Health and Social Secretariat of Manitoba. (2019). About Us. https://www .fnhssm.com/about-us.

First Nations Information Governance Centre. (April 7th, 2014). Barriers and levers for the implementation of OCAPTM. The International Indigenous Policy Journal, 5(2), 1-11. doi:10.18584/iipj.2014.5.2.3.

First Nations Information Governance Centre. (2016). Pathways to first nations' data and information sovereignty. In T. Kukutai, \& J. Taylor (Eds.), Indigenous Data Sovereignty: Toward an Agenda (pp. 139-155). Australian National University Press.

First Nations Information Governance Centre. (2018). The First Nations Principles of $O C A P \circledR$. https://fnigc.ca/ocap.

First Nations Information Governance Centre. (2019). First nations data sovereignty in Canada. Statistical Journal of the IAOS, 35(1), 47-69. doi:10.3233/SJI-180478.

Galloway, G. (2015). Trudeau vows to develop plan to put Canada on path to "true reconciliation". The Globe and Mail Canada. https://www.theglobeandmail.com/news /national/truth-and-reconciliation-head-calls-for-action-as-final-report-released/article $27762924 /$.

Goodleaf, D.K. (1995). Entering the War Zone: A Mohawk Perspective on Resisting Invasions. Theytus Books Limited.

Government of Canada, c. A-1, s. 13. (R.S.C., 1985a). Access to Information Act. https:// laws-lois.justice.gc.ca/eng/acts/a-1/.

Government of Canada, c. P-21, a. 3 "personal information" (m). (R.S.C., 1985b). Privacy Act. https://laws-lois.justice.gc.ca/ENG/ACTS/P-21/index.html. 
Government of Canada. (2014). Indian Health Policy 1979. https://www.canada.ca/en/ Indigenous-services-canada/corporate/first-nations-inuit-health-branch/indian-healthpolicy-1979.html.

Government of Canada. (2019). Canada's Health Care System. https://www.canada.ca/ en/health-canada/services/health-care-system/reports-publications/health-care-system/ canada.html.

Government of Canada. (2020). Jordan's Principle. https://www.canada.ca/en/Indigenous -services-canada/services/jordans-principle.html.

Gradual Civilization Act, CAP XXVI. (1857). http://www.caid.ca/GraCivAct1857.pdf.

Harris, S.B., Naqshbandi, M., Bhattacharyya, O., Hanley, A.J., Esler, J.G., Zinman, B., \& Group, C.S. (2011). Major gaps in diabetes clinical care among Canada's first nations: results of the CIRCLE study. Diabetes Research and Clinical Practice, 92(2), 272-279. doi:10.1016/j.diabres.2011.02.006.

Hart, M. (2002). Seeking Mino-Pimatisiwin: AN Aboriginal Approach to Helping. Fernwood Books Limited.

Indian Act, c.I-5. S.1. (R.S.C., 1985). https://laws-lois.justice.gc.ca/eng/acts/i-5/.

Indigenous and Northern Affairs Canada. (2010). Statement of Apology to Former Students of Indian Residential Schools. https://www.aadncaandc.gc.ca/eng/1100100015644/110 0100015649.

Indigenous and Northern Affairs Canada. (2017). United Nations Declaration on the Rights of Indigenous Peoples. https://www.aadncaandc.gc.ca/eng/1309374407406/130 9374458958.

Indigenous Corporate Training Inc. (2016). Hereditary Chief Definition and 5 FAQs. https ://www.ictinc.ca/blog/hereditary-chief-definition-and-5-faqs.

Inuit Tapiriit Kanatami. (2019). National Inuit Strategy on Research Roundtable: Summary Report. https://www.itk.ca/wpcontent/uploads/2019/11/ITK_NISR_Roundt able_11.pdf.

Inuit Tapiriit Kanatami. (2020). Inuit Tapiriit Kanatami. https://www.itk.ca/.

Katz, A., Kinew, K.A., Star, L., Taylor, C., Koseva, I., Lavoie, J., Burchill, C., Urquia, M.L., Basham, A., Rajotte, L., Ramayanam, V., Jarmasz, J., \& Burchill, S. (Fall, 2019). The Health Status of and Access to Healthcare by Registered First Nation Peoples in Manitoba. Manitoba Centre for Health Policy. http://mchpappserv.cpe.umanitoba.ca/ reference/FN_Report_web.pdf.

Ketonen, K. (2019). Trudeau commits to indigenous health care overhaul. CBC News. https ://www.cbc.ca/news/canada/thunder-bay/trudeau-Indigenous-health-care-1.5297959.

King, M., Smith, A., \& Gracey, M. (2009). Indigenous health part 2: the underlying causes of the health gap. The Lancet, 374(9683), 76-85. doi:10.1016/S0140-6736(09)60827-8.

Laanela, M. (September 30th, 2016). Orange shirt day: how Phyllis Webstad's 1st day at residential school inspired a movement. CBC News. https://www.cbc.ca/news/canada/ british-columbia/orange-shirt-day-1.3785597.

Library and Archives of Canada Act, S.C. c. 11. (2004). https://lawslois.justice.gc.ca/eng/ acts/L-7.7/.

MacDonald, N., \& Attaran, A. (August 14th, 2007). Jordan's principle, governments' paralysis. Canadian Medical Association Journal_CMAJ, 177(4), 321. doi:10.1503/ cmaj.070950.

MacDonald, C., \& Steenbeek, A. (2015). The impact of colonization and western assimilation on health and wellbeing of Canadian aboriginal people. International Journal of Regional and Local History, 10(1), 32-46. doi:10.1179/20514530 15Z.00000000023. 
Mamow Ahyamowen Partnership. (2019). Learning from our Ancestors: Mortality Experience of First Nations in Northern Ontario. https://mamowahyamowen.ca/wp-c ontent/uploads/2019/12/Mamow-Ahyamowen-Mortality-2019.pdf.

Mustimuhw Information Solutions. (n.d.). Designed by and for First Nations. http://www .mustimuhw.com/.

National Aboriginal Health Organization. (2017). About NAHO. https://wayback.archiveit .org/9444/20171213190657/http://www.naho.ca/about/.

National Inquiry into Missing and Murdered Indigenous Women and Girls. (2019). Reclaiming Power and Place: The Final Report of the National Inquiry into Missing and Murdered Indigenous Women and Girls, Volume 1a. https://www.mmiwg-ffada.c a/wp-content/uploads/2019/06/Final_Report_Vol_1a-1.pdf.

Philpott, J. (2018). Canada's efforts to ensure the health and wellbeing of indigenous peoples. The Lancet, 391(10131), 1650-1651. doi:10.1016/S0140-6736(18)30179-X.

Pyper, E., Henry, D., Yates, E.A., Mecredy, G., Ratnasingham, S., Slegers, B., \& Walker, J.D. (2018). Walking the path together: indigenous health data at ICES. Healthcare Quarterly, 20(4), 6-9. doi:10.12927/hcq.2018.25431.

Richmond, C.A.M., \& Cook, C. (2016). Creating conditions for Canadian aboriginal health equity: the promise of healthy public policy. Public Health Reviews, 37(2), 1-16. doi:10.1186/s40985-016-0016-5.

Royal Commission on Aboriginal Peoples. (1996). Report of the Royal Commission on Aboriginal Peoples. Library and Archives Canada. https://www.baclac.gc.ca/eng/discov er/aboriginal-heritage/royal-commission-aboriginal-peoples/Pages/final-report.aspx.

Saku, J.C. (1999). Aboriginal census data in Canada: a research note. The Canadian Journal of Native Studies, 19(2), 365-379. http://www3.brandonu.ca/cjns/19.2/cjnsv1 9no2_pg365-379.pdf.

Slater, M., Green, M.E., Shah, B., Khan, S., Jones, C.R., Sutherland, R., Jacklin, K., \& Walker, J.D. (2019). First nations people with diabetes in Ontario: methods for a longitudinal population-based cohort study. CMAJ Open, 7(4), E680-E688. doi:10.9778/cmajo.20190096.

Smylie, J., \& Firestone, M. (2015). Back to the basics: identifying and addressing underlying challenges in achieving high quality and relevant health statistics for indigenous populations in Canada. Statistical Journal of the IAOS, 31(1), 67-87. doi:10.3233/SJI-150864.

Smylie, J., Firestone, M., Spiller, M.W., \& Tungasuvvingat, I. (2018). Our health counts: population-based measures of urban Inuit health determinants, health status, and health care access. Canadian Journal of Public Health, 109(5-6), 662-670. doi:10.17269/ s41997-018-0111-0.

The Canadian Press. (2019a). Métis Nations Sign Historic Self-Governance Deal with Ottawa. https://globalnews.ca/news/5438360/metis-self-governance-alberta-ontario-sa skatchewan/.

The Canadian Press. (2019b). Trudeau Says Relationship with Metis is "Model of What Reconciliation Can Be”. https://globalnews.ca/news/5388102/trudeau-metis-nation -reconciliation/.

The Institute on Governance. (1997). Summary of the Final Report of the Royal Commission on Aboriginal Peoples. https://iog.ca/docs/1997_April_rcapsum.pdf.

Truth and Reconciliation Commission of Canada. (2015). Honouring the Truth, Reconciling for the Future: Summary of the Final Report of the Truth and Reconciliation Commission of Canada. http://www.trc.ca/assets/pdf/Honouring_the_Truth_Reconciling_for_the_F uture_July_23_2015.pdf. 
Tui'kn Partnership. (2015). Tui'kn Partnership: Because Health Belongs to All of Us. www.tuikn.ca.

Unist'ot'en Camp. (2020). Wet'suwet'en Supporter Toolkit 2020. http://unistoten.camp/ supportertoolkit2020/.

United Nations. (2016). United Nations Declaration on the Rights of Indigenous Peoples. https://www.un.org/development/desa/Indigenouspeoples/declaration-on-the-rights-of -Indigenous-peoples.html.

University of Manitoba. (2019). Manitoba Centre for Health Policy: First Nation People's Health in Manitoba. Manitoba Centre for Health Policy. https://d5d8ad59-8391-480 29f0af5f5d600d7e9.filesusr.com/ugd/38252a_e6cb8d7b16d64161976ce7bd4d49599e. pdf.

Vogal, L. (2015). Broken trust drives native health disparities. Canadian Medical Association Journal, 187(1), E9-E10. doi:10.1503/cmaj.109-4950.

Walker, J., Lovett, R., Kukutai, T., Jones, C., \& Henry, D. (2017). Indigenous health data and the path to healing. The Lancet, 390(10107), 2022-2023. doi:10.1016/ S0140-6736(17)32755-1.

Walker, J.D., Rowe, R., \& Jones, C.R. (2018). Describing the process of ethical conduct of research in an ontario-wide first nations diabetes research project. CMAJ, 190(Suppl), S19-S20. doi:10.1503/cmaj.180479.

Walker, J.D., Andrew, M., Bronskill, S., Smylie, J., Warry, W., Henry, D., Loft, D., Jones, C., Sutherland, R., Blind, M., Slater, M., Pitawanakwat, K., Mecredy, G., \& Jacklin, K. (2019). Ontario First Nations Aging Study: Overview and Report. Sudbury: Ontario First Nations Aging Study.

Walker, J.D., Slater, M., Jones, C.R., Shah, B.R., Frymire, E., Khan, S., Jacklin, K., \& Green, M.E. (2020). Diabetes prevalence, incidence and mortality in first nations and other people in ontario, 1995-2014: a population-based study using linked administrative data. CMAJ, 192(6), E128-E135. doi:10.1503/cmaj.190836.

Young, B. (2015). "Killing the Indian in the child": death, cruelty, and subjectformation in the Canadian Indian residential school system. Mosaic: A Journal for the Interdisciplinary Study of Literature, 48(4), 63-76. https://www.jstor.org/stable/4 4030407? seq=1. 